keywords: mineral resource base, geology, Centers for economic development, mineral resource potential, national mineral wealth, mineral resource base cost estimate, innovations, socio-economic development scenarios

O. V. Petrov

\title{
MINERAL RESOURCE POTENTIAL OF THE RUSSIAN FEDERATION: CONDITION AND INNOVATION USE TRENDS
}

The paper deals with the issues concerned with market appraisal of mineral resource potential of the Russian Federation. Strategy regarding reproduction and innovation use of the mineral resource potential on an expanded scale has been substantiated. Mineral resource potential of the Russian Federation is considered by the author as a major factor of budgeting and national well-being. The structure of national wealth (in terms of minerals) has been analyzed. New Centers for economic development have been justified; they are an essential supplemental base to the existing large oil-and-gas and mining regions with considerably depleted potential. The statement related to the fact that Centers for economic development are to be planned with regard to innovation development of the mineral resource base, has been substantiated.

The issue referred to innovation use of the mineral resource potential of Russia is vital due to the fact that mineral resources in Russia play a key role in budgeting and national well-being, and updated mechanisms of government regulation and innovation technologies for reproduction and development of the mineral resource base make national economy competitive.

The research results are included in the monograph "Mineral wealth of Russia. Appraisal of mineral resources and cost" (2008), "Atlas of principal deposits of the Russian Federation" and in multiple papers and speeches. The research work received approval of the relevant committees of the Federation Council and the State Duma, and also territorial and regional bodies of the Federal Agency for Subsoil Use (Rosnedra), Constituent Entities of the Russian Federation and Federal Districts. The research results provided the basis for a number of crucial decisions in the context of reproduction of Russian mineral resource base; the results have been applied by the Federal Agency for Subsoil Use and the administrative authorities of the Constituent Entities of Siberia and the Far East.

The research objective was updated market appraisal of the mineral resource potential of the Russian Federation and substantiation of strategies regarding expanded reproduction and innovation employment of such potential.

To achieve the objective:

1) geological and economic study and cost reappraisal of the Russian mineral resource base from the perspective of the world market conjuncture has been made;

2) mineral resource Centers for economic development (CEDs) intended for innovation development of raw material complex of Russia and enhancement of its competitive edge have been outlined;

3) based on the mentioned mineral resource centers for economic development (CED), strategies of geological research and license policy by the Rosnedra regarding expanded reproduction and innovation development of the mineral resource base of the Russian Federation have been determined and implemented.

The monograph and the "Atlas" includes description of the fields and their place in Russian and global subsoil management. Each mineral includes the following: deposit map; position of the Russian mineral resource base in reference to the global one; reserve and mining patterns according to deposits; specification of deposits in the State 
Reserves Register; material cost description of Russian mineral resource base referred to a particular mineral.

Thus, the Atlas is a concise and rather complete information system referred to the Russian mineral resource base and the main deposits.

In the context of modern trends of computer technology progress, a geo-information analytical system that facilitates access to the given information was generated based on the Atlas "Subsurface resources of Russia" by VSEGEI GIS and "Mineral resources of Russia" by GIAS.

Thus, all the branch-wise information regarding reserves and resources of minerals, namely, the State Reserves Register, deposit and exposure Cadastre, approved resources has been used for thorough geological and economic analysis of territorial allocation of the national mineral resource base.

To display mineral deposits playing the major role in generation and development of the Russian mineral resource base, a specific "Map of the main deposits with over $70 \%$ of reserves and annual production of minerals in Russia" was included in the atlas. The mineral resource potential and the extracted value of over 1000 subsurface sites of federal significance approved by the Government of the Russian Federation are presented on an individual geological and economic map.

As of the beginning of 2009, the State Reserves Register of Russia registered 12245 deposits according to 65 types of minerals, including solid minerals -7425 . The number of developed deposits of solid minerals is 1909 , which is only $38 \%$ of the registered by the State Reserves Register of Russia. Total 97 deposits, or approximately 5\% of their total amount, provide $70 \%$ of the produced mineral resources in the country.

In Russia, as well as worldwide, single large deposits with the majority of minerals determine mineral resource base formation and exploitation.

Cost estimate of the mineral resource base was accomplished based on the socio-economic rates according to the Constituent Entities of the Russian Federation for the period since 2000. Therewith, legal and tax policies of subsoil use effectual in Russia have been considered. Global and national prices for mineral resources as of January 2008 have been applied. In 2009 cost estimates have been updated.

To specify the Russian mineral wealth, a recovered value of mineral resources has been taken as a cost estimate. Output of the given mineral resources is cost effective, and reserves satisfy the demand predicted for 25-year term. In the context of calculation of the mineral wealth of Federal Districts and Constituent Entities of the Russian Federation, four levels according to the scale of the registered reserves and approved resources of different categories have been singled out. In-demand mineral wealth (IDMW) referred to deposits under development, and potential to be increased in the future for account of the reserves and resources of the unallocated subsoil reserve fund are of particular interest.

According to Figure 1, fossil fuels - chiefly, raw hydrocarbons, are substantial for the mineral wealth. Solid metal and non-metal minerals take approximately $10 \%$ in cost estimate of the mineral resource potential.

The Ural, Siberian, Privolzhsky Federal Districts yield over the half of total national mineral resources at all the four levels.

Therewith, 95-97\% of the mineral wealth of the Ural Federal District is represented by raw hydrocarbons.

Over the half of the actual mineral wealth of the Siberian Federal District is represented by highly liquid minerals (gold, nickel, copper, stibium, platinoids, oil, gas); three quarters - in the Privolzhsky Federal District, over the half - in the North-Western Federal District. Mineral wealth of the Southern Federal District is specified by $80 \%$ of highly liquid minerals, and the Far-Eastern Federal District - by three quarters. Up to $65 \%$ of the actual mineral wealth of the Central Federal District is represented by iron ore. The facts mentioned above are rather advantageous for the national mineral wealth within the framework of the Federal Districts. However, let us consider that the given administrative units are rather conventional, and they do not have appropriate infrastructure to develop the mineral resource base by way of innovations.

Thus, for instance, $90 \%$ of the explored coal reserves are located in the Asian part of Russia, yet they are allocated rather unevenly; and consumption orientation of the given reserves is more European. Although total reserves of iron ore are sufficient, iron and steel works of the Southern Urals and Western Siberia with two thirds of total ironworks capacity and only one third of iron ore production incur acute deficiency in the resources mentioned. Highly deficient kinds of minerals include manganese and chromium ore, titanium, zirconium and some others. A lot of minerals lack reserve base.

Therefore, to develop the national mineral resource base by way of innovations based on the geological, economic and cost analysis, 33 new mineral resource Centers for economic development (CEDs in the North-Western part of the country, the Urals, the South, Siberia and the Far East have been distinguished. 
20 CEDs in the territories of Siberia and the Far East have been justified. They are connected by infrastructure (TRANSIB, BAM railways; Barnaul - Chita - Khabarovsk motor roads; and power transmission lines). New feeders and oil and gas pipelines (Eastern Siberia - Pacific ocean) are under construction within the given area. There are investment projects intended for construction of new heat power plants, chains of power plants, metallurgical and other plants. Thus, mineral resource CEDs are essential for geological and socio-economic zoning of the Russian territory.

Derived values of minerals and other economic indices referred to RF Constituent Entities, Federal Districts and Russia in general are calculated for all such Centers.

The planned CEDs are a substantial supplement to the existing base of the oil-and-gas and mining areas, which are considerably exhausted.

As a result of effective geological exploration at the water area of the Caspian Sea and the bottom of the Volga river in 2000-2008, a mineral resource base was created with an objective to establish the Caspian Center for oil and gas extraction with annual capacity, according to one of the developers V.P. Orlov, of approx. 20 million tons of fuel equivalent; and up to 35-40 million tons of fuel equivalent in case if the existing deposits are taken into account. The Northern Center involves the Russian part of the Barents and the Pechora Seas' shelf plate, as well as the neighboring parts of the Nenets Autonomous District, the Murmansk and Arkhangelsk regions. A new unique area for hydrocarbon production will be Yamal-Kara Center, which involves the Kara Sea shelf plate, the Yamal peninsula, the Gulf of $\mathrm{Ob}$ and the western part of the Gydansky peninsula. In 2009, when oil production at the Vankor Field is launched, the Turuhansk Center will be established; it will produce about 30 million tons of oil.

Among other advanced Centers is the EastSiberian, involving the majority of oil and gas fields of Evenkia, the Republic of Sakha (Yakutia) and the Irkutsk Region. Along with large gas and chemical complexes, installation of gas service at industrial and social units, at construction, transport and power complexes, the East-Siberian Center will become a backbone element of a powerful industrial cluster by 2020 , with approx. 60 thousand new workplaces, 3035 million tons of oil production and 65-70 billion cubic meters of gas annually.

As to the Eastern part of the country, the SouthOkhotsk oil-and-gas Center based on the Sakhalin projects is being developed. Raw hydrocarbons are already being produced there within the scope of approx. 20 million tons of fuel equivalent; construction of the largest works for gas liquefaction was launched. By 2012-2013 annual capacity related to hydrocarbon production will reach $30-35$ million tons of fuel equivalent, by $2015-40-45$, and gas liquefaction capacity will amount to 9,6 million tons. The Sakhalin projects are executed by almost totally applying innovation technologies and advanced equipment.

And finally, establishment of the advanced North-Okhotsk Center is also to be mentioned; it involves northern parts of the water area of the Sea of Okhotsk and the Western part of the Kamchatka peninsula. Potential scale of annual production of raw hydrocarbons, according to OJSC "NK Rosneft", is estimated $25-30$ million tons of fuel equivalent.

Development of other mineral resource centers is planned on the basis of solid mineral field development.

In the context of consolidation of the sulphide nickel MRB with associated platinoids, the East Sayan Center in the south of the Krasnoyarsk area and the Irkutsk region (particularly in the Kanskaya metallogenic zone, which is most well-investigated) is the most advanced. The given region is already considered to be strategically appealing for the "Norilsk nickel" company - the world's largest producer of nickel. General estimate of the resource potential of the Kanskaya and Biryusinskaya metallogenic zones conforms to the estimate of analogous nickeliferous zones of Canada and Northern China. Thus, the East Sayan nickeliferous province can be considered as a new prospective CED with annual nickel output of at least 300 million tons in over 30 years; minimum 20 thousand people can be employed. The given province can make a worthy alternative to the depleting highgrade Norilsk deposits; therefore, it is a matter of national significance that development of the given area is launched as soon as possible.

As far as gold is concerned, the existing gold ore plants may be supplemented by the Yano-Kolymsky CED in the Magadan region and the Republic of Sakha (Yakutia). Its mining potential exceeds 5 thousand tons, and annual gold output can amount to minimum $100-120$ tons for over 50 years; at least 50-60 thousand people can be employed in the given geopolitical region. The Natalkinskoye field - the major object in the territory - can produce up to 40 tons of gold annually starting from 2012.

The West-Verkhoyansky CED has relatively equal area as the Yano-Kolymsky CED has, they adjoin in the North-West. Its silver ore potential (approx. 60 thousand tons) supplements the base of the Dukat Gold-Silver Ore Field and some others, and it is 
equivalent to the world-level provinces in terms of its potential. It can secure mineral production with annual silver output of 1000 tons for $35-40$ years. The quality of the ore is competitive with that produced at the Dukat Field, and several objects are already licensed. Growth in demand for silver is to motivate the Government, on the one hand, to reach the mentioned volume of production in as short time as possible; on the other hand, the Government should be interested in additional employment in the given geopolitical territory.

As to the East-Zabaykalsk CED, the reserve generated there will secure operation of the new mining-and-metallurgical integrated works with industrial capacity up to 4 thousand tons of stibium for over 30 years, which is ground to employ up to 7 thousand people. In relation to that, the project of development of the given region is already being implemented though private-public partnership; the given project allows for integrated mining with stibium ore and gold-stibium ore objects taken into consideration.

Along with the geological and economic analysis, socio-economic development scenarios for particular regions and the whole constituent entities have been elaborated based on realization of their mineral resource potential. Such work has been done in reference to a number of Russian regions.

Particularly, regarding the Chukotka Autonomous District, where destructive processes in the mineral resource sector had been acute since the beginning of the $90 \mathrm{~s}$, with large-scale population outflow to the continent, the calculations were based on the existing mineral resource base of solid minerals, and gold primarily. Thus, for instance, development of the Kupol field will make it possible to reach annual gold production of 15 thousand tons in the short term. Step-by-step implementation of basic points of the program suggested by us will be ground for development of not only gold fields, but also tin, copper and coal fields with phased growth of the GRP: by 2013 - 4 times as much, by $2025-$ 10 times as much. Alongside with that, the matter of consolidation of geopolitical interest by Russia in the Asia-Pacific region will be resolved.

Centers for economic development appear particularly significant in the context of integration of the Russian mineral resource base in the global system of economic relations. The Centers are indispensable for planning of mineral resource base reproduction activities and for making decision regarding subsurface use of certain objects. Besides, such Centers are required for substantiation of a master plan referred to allocation of mining, processing, service and infrastructure sectors of the Russian economy.

Centers for economic development are to be planned with regard to innovation development of the mineral resource base, i.e. when a territory comprising several close fields is settled, necessary industrial and social infrastructure is provided, and extracted raw minerals are exposed to high-level processing.

Such an innovation approach conforms to the fundamentals of the theory of economic planning by a soviet scientist N.N. Kolosovsky and the theory of industrial agglomeration development by Paul Krugman, an americal scientist and the Nobel Laureate (2008). According to the latter, certain conditions generate a so-called core, which eventually draws capitals and people together. Network cooperation accelerates introduction of innovations and affects rapid development of agglomeration.

That was the ground for the authors of the present paper to justify the strategy of geological research and the license policy by the Rosnedra.

Accumulation of the federal budget resources afforded an opportunity for the Rosnedra to execute highly efficient geological exploration during 20062008 within the selected CEDs. For instance, the following predicted resources were located and estimated in 8 such Centers last year: gold $-50 \%$, silver - 97\%, stibium, nickel and platinoids almost $100 \%$.

Work with an objective to allocate and estimate the predicted resources of over 40 types of solid minerals has been carried out for account of the Federal budget resources within particular CEDs. At object 151 (demonstrated on the slide) positive results are obtained. The next slide demonstrates the dynamics of subsoil value growth as a result of the geological exploration for account of the Federal budget resources. As we can see, growth in 2007 and 2008 exceeded the rates of 2006 almost four times as much.

Golden ore production has been markedly enhanced (the reserves are increased by $47 \%$ ) due to, uppermost, fundamental revaluation of two global giants - the Natalkinskoye and the Sukhoy Log fields, which contain almost half of the national economic resource base.

The research provided estimation of the scale of the national mineral resource wealth, its place with regard to the global resources, and different development scenarios referred to the mineral resource complex have been outlined. In point of fact, it was for the first time that cadastral appraisal of the subsoil was executed; it is based on the mining 
rent, which amounts to over $60-80 \%$ of the subsoil use profit in terms of particular types of minerals.

Thus, the given materials became the ground for the authors to make a geological and economic analysis and cost revaluation of the national mineral resource base with regard to the new global market conditions; Centers for economic development have been singled out, which secure innovation development of the national mineral resource base and enhancement of its competitive ability; strategies of geological research and license policy by the Rosnedra aimed at expanded reproduction of the national mineral resource base have been determined and implemented.
The research and information materials in the present work, in our opinion, will serve for long as fundamental information for the Government's strategic plans related to mineral resource development.

\section{References}

1. Mikhailov B.K., Petrov O.V., Kimelman S.A., Vorobyov Y. Y., Nezhensky I.A. and others. (2008). Mineral wealth of Russia. Mineral resource and cost analysis. Atlas of the Main Deposits of the Russian Federation. St.-Petersburg: VSEGEI Publ. 